\title{
Role of Community Nurses in Improving Caregivers' Ability in Caring for Children with ARFID (Avoidant Restrictive Food Intake Disorder)
}

\author{
Yoyok Bekti Prasetyo ${ }^{1 *}$, Sri Sunaringsih Ika Wardojo ${ }^{2}$, Indah Dwi Pratiwi ${ }^{3}$ \\ ${ }^{1,3}$ Department of Nursing, Faculty of Health Sciences, University of Muhammadiyah Malang, \\ Malang, Indonesia \\ ${ }^{2}$ Department of Physiotherapy, Faculty of Health Sciences, University of Muhammadiyah Malang, \\ Malang, Indonesia \\ *Corresponding author: yoyokbekti2@gmail.com
}

\begin{abstract}
Background: Community nurses have a vital role in improving the caregiver's ability to care for children with ARFID (Avoidant Restrictive Food Intake Disorder). Maternal and family beliefs about the potential risks and seriousness of their child who suffers from ARFID will result in their confidence. Objectives: This study aims to illustrate the role of nurses in improving caregiver skills in caring for children with ARFID based on Johnson's Behavioral System Model (JBSM), Health Believe Model (HBM), and Parents-Child Interaction Model (PCIM). Method: This research is a literature research of electronic databases using keywords of "community nurse", "carer", "ability", "Avoidant Restrictive Food Intake Disorder", "caring", and "role". The article used in this review is primary research article with no limiting method of research. Results The results of the data analysis obtained seven themes which were mutually open, related and connected to each other. They were (1) Attachment-affiliative, (2) dependency, (3) ingestive, (4) eliminative, (5) sexual, (6) achievement, and (7) aggressive / protective relationships. Conclusion: The development of caregiver skills in caring for children with ARFID will be very useful in preventing childhood malnutrition. Caregivers in this case the mother or caregiver can develop constructive behavior in accompanying children with eating disorder.
\end{abstract}

Keywords: role, community, nurse, carer, ability, caring, avoidant restrictive food intake disorder

\section{INTRODUCTION}

Community nurses have an extremely vital role in promoting the ability of caregivers in caring children with ARFID (Avoidant Restrictive Food Intake Disorder). A number of theories that can be developed by community nurses in this case include Johnson's Behavioral System Model (JBSM) and Health Belief Model (HBM). JBSM empirically refers to the nursing care carried out for facilitating an individual (caregiver) in effectively and efficiently behaving when nursing children with ARFID. The effective and efficient behavior in HBM is translated as the ability of a caregiver in predicting preventive measures, conducting screening, or controlling the condition of children with ARFID (Glanz, Rimer, \& Viswanath, 2008; Goong, Ryu, \& Xu, 2016; Purwanta, 2012).

ARFID is a new term for describing eating disorder in infancy and early childhood (toddler) with the characteristics of: refusing to eat, poor meal times, low eating skill which does not fit with the stage of child development, lack of interest in eating, avoidance based on 
sensory characteristics of food such as: food appearance, food aroma and taste, fear to eat like dysphagia, fear to swallow food (Fisher et al., 2014; Kostro, Lerman, \& Attia, 2014; Nicely, Lane-Loney, Masciulli, Hollenbeak, \& Ornstein, 2014), and failure in meeting appropriate nutritional and energy need. (Katzman, Stevens, \& Norris, 2014), which later causes one or more signs of significant weight loss, nutritional deficiency, high dependence on enteral feeding and oral nutritional supplements, and interference with psychosocial functioning (Berlin, Davies, Silverman, \& Rudolph, 2011; Sharp, Volkert, Scahill, Mccracken, \& Mcelhanon, 2016). Feeding difficulty in children is a serious problem as it has an impact on their future life cycle (Ágh et al., 2015; Campbell \& Peebles, 2014; Segovia, 2015; Uher \& Rutter, 2012).

Some clinical symptoms shown by children with feeding difficulties can be in the form of picky eating behavior with prevalence of 12\% - 50\% (Garg, Williams, \& Satyavrat, 2015), food allergies with prevalence of $17.3 \%$ (Edition et al., 2015), and other symptoms. Research results reveal that $58 \%$ of children aged $1-5$ suffer from feeding disorder with the following complaints; eating only less than one third of the portion $(27.5 \%)$, refusing to eat (24.8\%) and being fretful, unpleased, or angry (22.9\%), only liking one kind of food $(7.3 \%)$, only willing to drink milk (18.3\%), taking > 1 hour to eat (19.3\%), and taking something into mouth as to suck it (15.6\%). As much as $72 \%$ complaints have been experienced for more than 6 months, 50\% showing complaint of weight gain disturbance, $22 \%$ being fretful, $12 \%$ suffering from epigastrium pain, $10 \%$ suffering from back arching, and 6\% suffering from swallowing pain and frequent vomiting (Soedibyo \& Mulyani, 2009). There have been 11\% (Nakai et al., 2017), 12.4\% (Fisher et al., 2014), 22.5\% (Nicely et al., 2014), 5\% - 23\% (Strandjord et al., 2016) children reported to have suffered from ARFID.

The nutritional problems of Indonesian children in 2010 are evident from the prevalence of Low Birth Weight (LBW) of $8.8 \%$, prevalence of under-fives categorized into being stunted of 35.6\% (7.6 million out of 23 million under-fives) and prevalence of thin children of 13.3\% (Coordinating Ministry of People's Welfare, 2012). The prevalence of children suffering from eating disorder is $15 \%$ in female children and $3 \%$ in male children (Hay \& Claudino, 2012), 30\% in female children and 15\% in male children (Campbell \& Peebles, 2014), 5\% - 14\% and potentially increase to $22.5 \%$ (Katzman et al., 2014; Norris \& Katzman, 2015). Among six-to-fifteen-month-old infants, it is reported by caregiver that $6 \%$ of them suffer from eating disorder and this figure will increase to $25-40 \%$ in the following stage of development (Sacrato, Pellicciari, \& Franzoni, 2010).

The eating disorder in infants and toddlers is caused by several factors, including: genetic and biological factor, environmental and sociocultural influences, and psychological stress (Campbell \& Peebles, 2014; De Luca \& Napoletani, 2015), mother and family factor (Allen et al., 2014), and dysfunctional interaction between mother and child (Goulding et al., 2014; Gueron-Sela, Atzaba-Poria, Meiri, \& Yerushalmi, 2011; Kröller \& Warschburger, 2009; Sacrato et al., 2010; Squires, Lalanne, Murday, Simoglou, \& Vaivre-Douret, 2014). The prevalence of affectionate tension between parents and child is $13-82 \%$, depending on the risk factor in the family such as negligence or maltreatment to the child (Skovgaard Væver, Smith-Nielsen, \& Lange, 2016).

The improvement of the ability of caregivers becomes an extremely significant variable in nursing children with ARFID by considering some causing factors such as genetic-biological factor, environment, psychological stress, mother and family factor, and interaction between mother and child (Frank, Roubal, Breitzer, \& Godin, 2016; Masse, McNeil, Wagner, \& Quetsch, 2016; Shumaker, Ockene, \& Riekert, 2009). Very strong environment influence will disturb the balance of behavioral system and will threaten one's stability in behaving (Dovey, Isherwood, Aldridge, \& Martin, 2015; Sidor, Fischer, Eickhorst, \& Cierpka, 2013; Yoo, Popp, \& Robinson, 2014). 
Psychological stress factor and mother-family factor may influence the belief of mother and family. The belief of the mother and family on the risk potential and the level of seriousness in children suffering from ARFID will yield in the belief of impeding threat. The interference on the belief on this threat will impact on the belief of the mother and family to have positive behavior in nursing children with ARFID (Dong et al., 2016; Gueron-Sela et al., 2011; Poortaghi et al., 2015). The factor interaction between mother and child can be described as the sensitivity between mother and child in capturing the existing signals or clues from ARFID case, which may cause effective and efficient behavior (Colegrove \& Havighurst, 2016; Merwin, Advisor, \& Gray, 2010). The idea of this research aims to describe the role of a nurse in promoting the ability of caregivers in nursing children with ARFID based on Johnson's Behavioral System (JBSM), Health Believe Model (HBM) and Parents-Child Interaction Model (PCIM) theories.

\section{METHOD}

This research is a literature research of electronic databases using keywords of "community nurse", "carer", "ability", "Avoidant Restrictive Food Intake Disorder", "caring", and "role". The article used in this review is primary research article with no limiting method of research. Results The results of the data analysis obtained seven themes which were mutually open, related and connected to each other. They were (1) Attachment-affiliative, (2) dependency, (3) ingestive, (4) eliminative, (5) sexual, (6) achievement, and (7) aggressive / protective relationships.

\section{RESULTS AND DISCUSSION}

\section{Johnson's Behavioral System Model concept in promoting the ability of caregivers in nursing children with ARFID}

Nurses significantly contribute toward the facilitation of effective patient functional behavior before, during and after illness (Tomey \& Alligood, 1998; Tuneh, 2016). There are 7 internal subsystems that are open, related and connected to each other, namely: attachmentaffiliative subsystem, dependency subsystem, ingestive subsystem, eliminative subsystem, sexual subsystem, achievement subsystem, and aggressive/protective subsystem).

\section{Attachment-affiliative subsystem}

Attachment-affiliative subsystem refers to the behavior required to achieve security needed to survive, such as social inclusion, intimacy and forms for maintaining social cohesion (Fawcett, 2017), something that is essential and basic from all social organizations (Tomey \& Alligood, 1998), as an early response to the development of an individual (George, 1995; Madlala, 2015). The social cohesion created in the environment covers the relationship with family and friends (Tuneh, 2016). The purpose of attachment-affiliative system is to protect one from danger (George, 1995; Milberg \& Friedrichsen, 2017). The affection from parents will have a long-term role in the neurological development of the child (Lavallée, Aita, Bourbonnais, \& De Clifford-Faugère, 2017). The ability of a child in coping with stress and managing negative emotion becomes the outcomes of social competence, moral and empathy development, and academic achievement (Skovgaard Væver et al., 2016).

\section{Dependency subsystem}

Dependency subsystem refers to the behavior of providing help/assistance as a response to the nursing given in the form of attention and acknowledgement and physical 
assistance (Fawcett, 2017). As to dependence, it is defined as "...its clearly not in control of itself" (Groarke, 2016). Dependency subsystem may help improve behavioral response to mutually give and care. Dependency subsystem is highly influenced by attachment-affiliative subsystem. The provision of affection from the caregiver to the child is the response given from the dependency behaviors shown by the child.

It is difficult to separate the dependency subsystem from affiliative or attachment subsystem because without someone invested in or attached to the individual to respond to that individual's dependency behaviors, the dependency subsystem has no animate environment in which to function (George, 1995)

Dependency is a state of relying on or needing someone for aid, support reliance confidence or trust (Madlala, 2015)

...it deals with the presence of people around the patient, the physical contact, group therapy is also good to create system to give patients support through their ordeal (Tuneh, 2016)

Dependency subsystem is defined as succoring behavior that calls for a response of nurturance as well as approval, attention or recognition, and physical assistance (Fawcett, 2017).

Children has a high dependency upon their parents or caregivers associated with the fulfillment of food needs (Hansson et al., 2016; Herschell, Scudder, Schaffner, \& Slagel, 2016). Children with eating disorders are strongly influenced by dependency (Ben-Porath, Federici, Wisniewski, \& Warren, 2014), so that in order to create good eating behaviors, parents or caregivers need to continuously improve children's independence in meeting their own needs (Cullinane \& Novak, 2013).

\section{Ingestive / eliminative subsystem}

The ingestive subsystem is associated with a sense of satisfaction in food intake. This behavior is related to social, psychological, and biological considerations. Ingestive is related to how, when, how, and how much to eat and drink as a behavioral subsystem. This is considered as a source in maintaining integrity and achieving pleasure in achieving environmental recognition. The ingestive subsystem is also related to the behavior of food intake (Fawcett, 2017; Tomey \& Alligood, 1998).

On the other hand, the eliminative sub-system is associated with behavioral satisfaction in terms of a person's elimination system "... the excretion of waste products form the body" (George, 1995). This elimination system is related to the ability to dispose of body waste metabolism. Satisfaction is linked very strongly with security, trust, and confidence and it also influenced by personal opinions, beliefs, expectations, and experiences (Condelius $\&$ Andersson, 2015). Family satisfaction is a protective factor in children with eating disorders (Allen et al., 2014).

\section{Sexual subsystem}

The sexual subsystem describes the behavior associated with procreation (affectionate / loving). In sexual subsystems, there are two functions, they are procreation (giving love / love) and gratification (mutual give satisfaction). The key words of this sexual subsystem is that in all communities having the same goal which is behavior that is acceptable by the larger community (Tomey \& Alligood, 1998).

Sexuality is an issue related to a quality in life. JBSM provides direction related to sexual behavior in several components including: communication, appearance, desire, stimulation, activity level, technique and orgasm. Communication is defined as a verbal conversation with a partner. The appearance is conceptualized as a physical appearance between the two that is when dressed or when not dressed. Desire is an interest to engage in 
sexual acts both alone and with a partner. Stimulation interpreted as a physical manifestation of desires such as lubrication of the vagina. Activity levels are defined between both initiation and frequency of sexual activity. Techniques are the various positions which are used during sexual activity. Orgasm is defined as the ability to get the peak of pleasure (Wilmoth \& Tingle, 2001).

\section{Aggressive subsystem}

Aggressive subsystem is a form of self-defense mechanism or protection from various threats in the neighborhood (Tomey \& Alligood, 1998), protection or self-preservation and social behavior (Fawcett, 2017). Protecting behavior and maintaining this behavior will result in a therapeutic relationship between caregivers and children (Curcio, 2017). In cases of children with ARFID who are depressed, they need help from family members or carers to provide protection, direction, and family support (Cismaru \& Pioufle, 2016).

\section{Achievement Subsystem}

Achievement is the level of achievement through creative skills in the one's life behavior. Achieving control or self-control or the environment through the search for some standard of perfection, such as physical, social, or creative skills. Mothers who are relatively young will have limited educational experience and low incomes (Catherine et al., 2016). This factor is associated with increased injury to children and development of low cognitive behavior in children.

\section{The concept of Health Belief Model (HBM) in improving caregiver skills in caring for children with ARFID}

HBM is one of the theories used to determine the ability of a person to take a preventive action measures against disease and health promotion (Akey, Rintamaki, \& Kane, 2013), explaining on why a person changes or maintains specific health behaviors (James, Pobee, Oxidine, Brown, \& Joshi, 2012; Poortaghi et al., 2015), explaining on why a person fails to participate in activities which are aimed to detect or to prevent disease (Borowski \& Tambling, 2015), predicting a person to take action in prevention, screening, or controlling sickness Glanz et al., 2008). To sum up, HBM is the underlying theory of caregivers to behave well in the level of prediction, to take action, and to change the behavior in caring for children with ARFID.

The main concepts in HBM include five health-related attitudinal factors namely: perceived susceptibility, perceived severity, perceived benefit, perceived barrier and perceived self -efficacy) (Glanz et al., 2008; Rahmati-najarkolaei, Rahnama, Fesharaki, \& Behnood, 2016; Shumaker et al., 2009). Perceived susceptibility is a belief about the probability of gaining illness or disease conditions (Glanz et al., 2008). Confidence in vulnerability is associated with risk as health conditions develop (Borowski \& Tambling, 2015). Carers or families who are caring for children with ARFID often do not realize or deny that their children have a health problem. This parents' rejection in eating disorders' cases is equivalent with low perceived susceptibility which will ultimately lead to the caregivers' unenthusiastic to look for changes.

Perceived severity is related to the difficulties or consequences of individual beliefs resulting from the conditions occurring. More difficulty levels or negative consequences about a condition will lead a person to take precautions over his condition (Borowski \& Tambling, 2015). The combination of perceived susceptibility and severity will lead to the new terminology which is perceived threat (Abuadas, Petro-Nustas, Albikawi, \& Nabolsi, 2016; Glanz et al., 2008; Shumaker et al., 2009). 
Perceived benefits is defined as the emergence of perceptions to change behavior because of one's awareness to their vulnerability of the seriousness of their health condition (perceived threat) (Sarver, Cichra, \& Kline, 2015; Surdej, 2016; Thomson, Buckley, \& Brinkworth, 2016). This behavior is a useful behavior to reduce the risks or threats of children with ARFID. Perceived barriers are potential negative aspects of health-promoting actions. Acceptance of barriers becomes the most significant predictor of action (Borowski \& Tambling, 2015). Cues to action is a modifying factor that will influence the behavior directly and indirectly through perceived threats and perceived benefits (Hanson \& Benedict, 2002). Perceived self-efficacy is defined as a belief for success in carrying out behaviors that lead to results to be achieved (Colditz et al., 2015; Dawson, Mullan, \& Sainsbury, 2014).

\section{CONCLUSIONS}

The development of caregiver skills in caring for children with ARFID will be very useful in preventing childhood malnutrition. Mother may develop constructive behavior in accompanying children with eating disorder. This will contribute to support the Sustainable Development Goals (SDGs) program. Nutrition policies in SDGs include reducing the incidence of stunting and wasting failure and reducing child mortality and morbidity due to infectious diseases related to nutritional disorders (Knowles et al., 2015). Further development of a study is the needs to analyze: a) the influence of the caregiver's behavioral system (affection, dependency, ingestive / elimination, sexual, aggressive, attainment of caregiver's behavior in caring for children with ARFID, and b) the influence of caregiver behavior (vulnerability beliefs, beliefs Seriousness, confidence of barriers, beliefs of benefit, self-efficacy) towards the upgrading of caregivers in caring for children with ARFID.

\section{REFERENCES}

Abuadas, M. H., Petro-nustas, W., Albikawi, Z. F., \& Nabolsi, M. (2016). Transcultural adaptation and validation of champion's health belief model scales for prostate cancer screening, Journal of Nursing Measurement, 24(2), 296-314.

Ágh, T., Kovács, G., Pawaskar, M., Supina, D., Inotai, A., \& Vokó, Z. (2015). Epidemiology, health-related quality of life and economic burden of binge eating disorder: a systematic literature review. Eating and Weight Disorders, 20(1), 1-12. doi: 10.1007/s40519-014-0173-9

Akey, J. E., Rintamaki, L. S., \& Kane, T. L. (2013). Health belief model deterrents of social support seeking among people coping with eating disorders. Journal of Affective Disorders, 145(2), 246-252. doi:10.1016/j.jad.2012.04.045

Allen, S. L., Smith, I. M., Duku, E., Vaillancourt, T., Szatmari, P., Bryson, S., ... Georgiades, S. (2014). Behavioral pediatrics feeding assessment scale in young children with autism spectrum disorder: Psychometrics and associations with child and parent variables. Journal of Pediatric Psychology, 40(6), 581-590. doi:10.1093/jpepsy/jsv006

Ben-Porath, D. D., Federici, A., Wisniewski, L., \& Warren, M. (2014). Dialectical behavior therapy: does it bring about improvements in affect regulation in individuals with eating disorders? Journal of Contemporary Psychotherapy, 44(4), 245-251. doi:0.1007/s10879-014-9271-2

Berlin, K. S., Davies, W. H., Silverman, A. H., \& Rudolph, C. D. (2011). Assessing familybased feeding strategies, strengths, and mealtime structure with the feeding strategies questionnaire. Journal of Pediatric Psychology, 36(5), 586-595. doi:10.1093/jpepsy/jsp107 
Borowski, S. C., \& Tambling, R. B. (2015). Applying the health belief model to young individuals' beliefs and preferences about premarital counseling, The Family Journal, 23(4), 417-426. doi:10.1177/1066480715602221

Campbell, K., \& Peebles, R. (2014). Eating disorders in children and adolescents: state of the art review. Pediatrics, 134(3), 582-592. doi:10.1542/peds.2014-0194

Catherine, N. L. A., Gonzalez, A., Boyle, M., Sheehan, D., Jack, S. M., Hougham, K. A., ... Waddell, C. (2016). Improving children's health and development in British Columbia through nurse home visiting: a randomized controlled trial protocol. BMC Health Services Research, 16(1), 349. doi:10.1186/s12913-016-1594-0

Challenge, T., \& Countries, D. (2015). Universal sustainable understanding the transformational challenge for developed countries report of a study by stakeholder forum, (May).

Cismaru, M., \& Pioufle, A. Le. (2016). Helping families affected by depression: incorporating prosocial and caregiving literature. International Business Research 9(12), 23-31. doi:10.5539/ibr.v9n12p23

Colditz, P., Sanders, M. R., Boyd, R., Pritchard, M., Gray, P., O'Callaghan, M. J., ... Jardine, L. (2015). Prem Baby Triple P: a randomised controlled trial of enhanced parenting capacity to improve developmental outcomes in preterm infants. BMC Pediatrics, 15(1), 15. doi:10.1186/s12887-015-0331-x

Colegrove, V. M., \& Havighurst, S. S. (2016). Review of nonverbal communication in parent???child relationships: assessment and intervention. Journal of Child and Family Studies, 1-17. doi:10.1007/s10826-016-0563-X

Condelius, A., \& Andersson, M. (2015). Exploring access to care among older people in the last phase of life using the behavioural model of health services use: a qualitative study from the perspective of the next of kin of older persons who had died in a nursing home. BMC Geriatrics, 15(1), 138. doi:10.1186/s12877-015-0126-9

Cullinane, D., \& Novak, P. (2013). Parent's/caregiver's relationship and the impact on nutrition, ICAN: Infant, Child, \& Adolescent Nutrition, 5(5), 2013-2016. doi:10.1177/1941406413496569.

Curcio, D. L. (2017). The lived experiences of nurses caring for dying pediatric patients. Pediatric Nursing, 43(1).

Dawson, L., Mullan, B., \& Sainsbury, K. (2014). Using the theory of planned behaviour to measure motivation for recovery in anorexia nervosa. Appetite, 84, 309-315. doi.org:10.1016/j.appet.2014.10.028

De Luca, G., \& Napoletani, M. (2015). Premonitory symptoms of Feeding and Eating Disorders in pediatric age. Italian Journal of Pediatrics, 41(Suppl 2), A25. doi:10.1186/1824-7288-41-S2-A25

Dong, F., Howard, A. G., Herring, A. H., Thompson, A. L., Adair, L. S., Popkin, B. M., ... Gordon-Larsen, P. (2016). Parent-child associations for changes in diet, screen time, and physical activity across two decades in modernizing China: China Health and Nutrition Survey 1991-2009. International Journal of Behavioral Nutrition and Physical Activity, 13(1), 118. doi:10.1186/s12966-016-0445-z

Dovey, T. M., Isherwood, E., Aldridge, V. K., \& Martin, C. I. (2015). Typology of Feeding Disorders Based Formulation of a Clinical Decision-Making Model. ICAN: Infant, Child, \& Adolescent Nutrition, 2(1), 45-51. doi:10.1177/1941406409359350.

Edition, S., Monte, C. M. G., Giugliani, E. R. J., Security, F., Affected, F. F., Prices, V. F., ... Agostoni, C. (2015). Recommendations on complementary feeding for healthy, fullterm infants. Jornal de Pediatria, 13(1), 36. doi:10.1186/s12887-015-0398-4

Fawcett, J. (2017). Applying conceptual models of nursing: quality improvement, research, and practice. New York: Springer Publishing Company. 
Fisher, M. M., Rosen, D. S., Ornstein, R. M., Mammel, K. A., Katzman, D. K., Rome, E. S., ... Walsh, B. T. (2014). Characteristics of avoidant/restrictive food intake disorder in children and adolescents: A "new Disorder" in DSM-5. Journal of Adolescent Health, 55(1), 49-52. doi:10.1016/j.jadohealth.2013.11.013

Frank, S. J., Roubal, K. C., Breitzer, G. M., \& Godin, J. L. (2016). Separating the Effects of Child Problems and Parent-Child Interactions on Caregiver Strain. Journal of Child and Family Studies, 1-14. doi:10.1007/s10826-016-0560-0

Garg, P., Williams, J. A., \& Satyavrat, V. (2015). A pilot study to assess the utility and perceived effectiveness of a tool for diagnosing feeding difficulties in children. Asia Pacific Family Medicine, 1-8. doi:10.1186/s12930-015-0024-5

George, J. B. (1995). Nursing theories the base of professional nursing practice (4th ed). East Norwalk, Connecticut: Appleton \& Lange A Simon \& Schuster Company.

Glanz, K., Rimer, B. K., \& Viswanath, K. (2008). Health behavior and health education: theory, research, and practice. (C. T. Orleans, Ed.) (4th ed). San Francisco: JosseyBass.

Goong, H., Ryu, S., \& Xu, L. (2016). A structural model of health behavior modification among patients with cardiovascular disease. Applied Nursing Research, 29, 70-75. doi:10.1016/j.apnr.2015.06.005

Goulding, a N., Rosenblum, K. L., Miller, a L., Peterson, K. E., Chen, Y. P., Kaciroti, N., \& Lumeng, J. C. (2014). Associations between maternal depressive symptoms and child feeding practices in a cross-sectional study of low-income mothers and their young children. International Journal of Behavioral Nutrition and Physical Activity, 11(1), 111. doi:10.1186/1479-5868-11-75

Groarke, S. (2016). Though he slay me, yet will I trust in him: a critical reconstruction of Winnicott's theory of value. International Journal of Psychoanalysis, 97(4), 10351056. doi:10.1111/1745-8315.12411

Gueron-Sela, N., Atzaba-Poria, N., Meiri, G., \& Yerushalmi, B. (2011). Maternal worries about child underweight mediate and moderate the relationship between child feeding disorders and mother-child feeding interactions. Journal of Pediatric Psychology, 36(7), 827-836. doi:10.1093/jpepsy/jsr001

Haddad, L., Achadi, E., Bendech, M. A., Ahuja, A., Bhatia, K., Bhutta, Z., ... Martin-pr, Y. (2015). The Global Nutrition Report 2014: Actions and accountability to accelerate the world health organization. Progress on Nutrition $1-4$, 663-671. doi:10.3945/jn.114.206078.663

Hanson, J. A., \& Benedict, J. A. (2002). Use of the health belief model to examine older adults' food-handling behaviors. Journal of Nutrition Education and Behavior, 34, S25-S30. doi:10.1016/S1499-4046(06)60308-4

Hansson, L. M., Heitmann, B. L., Larsson, C., Tynelius, P., Willmer, M., \& Rasmussen, F. (2016). Associations between swedish mothers ' and 3- and 5-year-old children' s food intake. Journal of Nutrition Education and Behavior, 48(8), 520-529.e1. doi:10.1016/j.jneb.2016.05.015

Hay, P. J., \& Claudino, A. M. (2012). Clinical psychopharmacology of eating disorders: a research update. The International Journal of Neuropsychopharmacology, 15(4), 209222. doi:10.1017/S1461145711000460

Herschell, A. D., Scudder, A. B., Schaffner, K. F., \& Slagel, L. A. (2016). Feasibility and effectiveness of parent-child interaction therapy with victims of domestic violence: a pilot study. Journal of Child and Family Studies, 1-13. doi:10.1007/s10826-016-0546$\mathrm{y}$

James, D. C. S., Pobee, J. W., Oxidine, D., Brown, L., \& Joshi, G. (2012). Using the health belief model to develop culturally appropriate weight-management materials for 
african-american women. Journal of the Academy of Nutrition and Dietetics, 112(5), 664-670. doi:10.1016/j.jand.2012.02.003

Jha, A., Kickbusch, I., Programme, G. H., \& Taylor, P. (2016). Accelerating achievement of the sustainable: a game changer in global health, BMJ, 409(January), 1-2. doi:10.1136/bmj.i409

Katzman, D. K., Stevens, K., \& Norris, M. (2014). Redefining feeding and eating disorders : What is avoidant / restrictive food intake disorder? Paediatrics Child Health, 19(8), 445-446. Retrieved from http://www.cpsp.cps.ca/uploads/publications/Highlightsavoidant-restrictive-food-intake-disorder.pdf

Kementerian Koordinator Bidang Kesejahteraan Rakyat. (2013). Kerangka kebijakan gerakan nasional percepatan perbaikan gizi dalam rangka seribu hari pertama kehidupan (Gerakan 1000 HPK), 71.

Knowles, S. E., Chew-Graham, C., Adeyemi, I., Coupe, N., Coventry, P. A., Ferrari, A., ... McKnight-Eily, L. (2015). Managing depression in people with multimorbidity: a qualitative evaluation of an integrated collaborative care model. BMC Family Practice, 16(1), 32. https://doi.org/10.1186/s12875-015-0246-5

Kostro, K., Lerman, J. B., \& Attia, E. (2014). The current status of suicide and self-injury in eating disorders: a narrative review. Journal of Eating Disorders, 2, 19. doi:10.1186/s40337-014-0019-x

Kröller, K., \& Warschburger, P. (2009). Maternal feeding strategies and child's food intake: considering weight and demographic influences using structural equation modeling. The International Journal of Behavioral Nutrition and Physical Activity, 6, 78. doi:10.1186/1479-5868-6-78

Lavallée, A., Aita, M., Bourbonnais, A., \& De Clifford-Faugère, G. (2017). Effectiveness of early interventions for parental sensitivity following preterm birth: a systematic review protocol. Systematic Reviews, 6(1), 62. doi:10.1186/s13643-017-0459-x

Madlala, S. T. (2015). Perceptions of young males at the free state school of nursing with regards to teenage pregnancy.

Masse, J. J., McNeil, C. B., Wagner, S., \& Quetsch, L. B. (2016). Examining the Efficacy of Parent???Child Interaction Therapy with Children on the Autism Spectrum. Journal of Child and Family Studies, 25(8), 2508-2525. doi:10.1007/s10826-016-0424-7

Merwin, S., Advisor, C., \& Gray, J. (2010). Feeding disorders of infants and toddlers: a follow-up to the treatment of infantile anorexia.

Milberg, A., \& Friedrichsen, M. (2017). Attachment figures when death is approaching: a study applying attachment theory to adult patients' and family members' experiences during palliative home care. Supportive Care in Cancer. doi:10.1007/s00520-017-36347

Nakai, Y., Nin, K., Noma, S., Hamagaki, S., Takagi, R., Teramukai, S., \& Wonderlich, S. A. (2017). Clinical presentation and outcome of avoidant/restrictive food intake disorder in a Japanese sample. Eating Behaviors, 24, 49-53. doi:10.1016/j.eatbeh.2016.12.004

Nelson, C. A. (2015). Prologue: How Do We Share the Future? doi:10.1177/1946756715569221

Nicely, T. A., Lane-Loney, S., Masciulli, E., Hollenbeak, C. S., \& Ornstein, R. M. (2014). Prevalence and characteristics of avoidant/ restrictive food intake disorder in a cohort of young patients in day treatment for eating disorders. Journal of Eating Disorders, 2(2 SUPPL. 1), S38. doi:10.1016/j.jadohealth.2012.10.092

Norris, M. L., \& Katzman, D. K. (2015). Change is never easy, but it is possible: reflections on avoidant/restrictive food intake disorder two years after its introduction in the DSM5. Journal of Adolescent Health, 57(1), 8-9. doi:10.1016/j.jadohealth.2015.04.021 
Peraturan presiden. (2013). Perpres No. 42 Tahun 2013 Tentang Gerakan Nasional Percepatan Perbaikan Gizi, (1), 1-16.

Poortaghi, S., Raiesifar, A., Bozorgzad, P., Golzari, S. E. J., Parvizy, S., \& Rafii, F. (2015). Evolutionary concept analysis of health seeking behavior in nursing: a systematic review. BMC Health Services Research, 15(1), 523. doi:10.1186/s12913-015-1181-9

Purwanta, E. (2012). Modifikasi perilaku: alternatif penanganan anak berkebutuhan khusus. Yogyakarta: Pustaka Pelajar.

Rahmati-najarkolaei, F., Rahnama, P., Fesharaki, M. G., \& Behnood, V. (2016). Predictors of oral health behaviors in female students: the application of the health belief model. Iranian Red Crescent Medical Journal, 18(11), 1-6. doi:10.5812/ircmj.24747

Sacrato, L., Pellicciari, A., \& Franzoni, E. (2010). Emergent factors in eating disorders in childhood and preadolescence. Italian Journal of Pediatrics, 36, 49. doi:10.1186/18247288-36-49

Sarver, W., Cichra, N., \& Kline, M. (2015). Perceived benefits, motivators, and barriers to advancing nurse education: removing barriers to improve success. Nursing Education Perspectives, 36(3), 153-157. doi:10.5480/14-1407

Segovia, M. J. G. (2015). Psychological and psychological impairment in preschoolers with selective eating. Acta Pediatrica Espanola, 73(9), 240. doi:10.1542/peds.2014-2386

Sharp, W. G., Volkert, V. M., Scahill, L., Mccracken, C. E., \& Mcelhanon, B. (2016). A systematic review and meta-analysis of intensive multidisciplinary intervention for pediatric feeding disorders: how standard is the standard of care? The Journal of Pediatrics, 181, 116-124.e4. doi:10.1016/j.jpeds.2016.10.002

Shumaker, S. A., Ockene, J. K., \& Riekert, K. A. (2009). The handbook of health behavior change (3rd Ed). New York.

Sidor, A., Fischer, C., Eickhorst, A., \& Cierpka, M. (2013). Influence of early regulatory problems in infants on their development at 12 months: a longitudinal study in a highrisk sample. Child and Adolescent Psychiatry and Mental Health, 7(1), 35. doi:10.1186/1753-2000-7-35

Skovgaard Væver, M., Smith-Nielsen, J., \& Lange, T. (2016). Copenhagen infant mental health project: Study protocol for a randomized controlled trial comparing Circle of Security-Parenting and care as usual as interventions targeting infant mental health risks. BMC Psychology, 4, 57. doi:10.1186/s40359-016-0166-8

Soedibyo, S., \& Mulyani, R. L. (2009). Kesulitan Makan pada Pasien: Survei di Unit Pediatri Rawat Jalan. Sari Pediatri, 11(2), 79-84.

Squires, C., Lalanne, C., Murday, N., Simoglou, V., \& Vaivre-Douret, L. (2014). The influence of eating disorders on mothers' sensitivity and adaptation during feeding: a longitudinal observational study. BMC Pregnancy and Childbirth, 14, 274. doi:10.1186/1471-2393-14-274

Strandjord, S. E., Sabik, J., Nahra, A., Abdulkader, Z., Sieke, E. H., Worley, S., \& Rome, E. S. (2016). Avoidant/restrictive food intake disorder: treatment choice and outcome in the outpatient setting. Journal of Adolescent Health, 58(2), S37-S38. doi:10.1016/j.jadohealth.2015.10.088

Surdej, S. M. (2016). Barriers, supporting factors, and perceived benefits that influence mother's decision to stop or continue to breastfeed.

Thomson, R. L., Buckley, J. D., \& Brinkworth, G. D. (2016). Perceived exercise barriers are reduced and benefits are improved with lifestyle modification in overweight and obese women with polycystic ovary syndrome: a randomised controlled trial. BMC Women's Health. doi:10.1186/s12905-016-0292-8

Tomey, A. M., \& Alligood, M. R. (1998). Nursing theorists and their work. (L. S. Wilson, Ed.) (4th editio). St. Louis, Missouri: Mosby-Year Book, Inc. 
Tuneh, E. (2016). Nursing intervention to enhance the quality of life for the alzheimer's disease patient.

Uher, R., \& Rutter, M. (2012). Classification of feeding and eating disorders: Review of evidence and proposals for ICD-11. World Psychiatry, 11(2), 80-92. doi:10.1016/j.wpsyc.2012.05.005

Wilmoth, M. C., \& Tingle, L. R. (2001). Development and psychometric testing of the wilmoth sexual behaviors quetionnaire-female. Canadian Journal of Nursing Research, 32(4), 135-151.

Yoo, Y. S., Popp, J., \& Robinson, J. (2014). Maternal distress influences young children's family representations through maternal view of child behavior and parent-child interactions. Child Psychiatry and Human Development, 45(1), 52-64. doi:10.1007/s10578-013-0377-7 